JURNAL PARIWISATA BUDAYA, VOLUME 3, NOMER 2, TAHUN 2018

HALAMAN 24-26

\title{
Tradisi Magoak-Goakan pada Nyepi Desa \\ Sebagai Potensi Daya Tarik Wisata Spiritual Di Desa Tambakan \\ Kecamatan Kubutambahan Kabupaten Buleleng.
}

I Ketut Wardana Yasa

Dosen Fakultas Dharma Duta IHDN Denpasar

\begin{abstract}
The tourism development such as beach, mountain, temples, and dance or other tourist attractions are ussual we can see in Bali. But one of the most rare tradition which is carried out by the peoples in Tambakan Village is Megoak Goakan as part of Silent day Ceremony which is held every one year. This tradition was held from Ngurah Panji Sakti Kingdom in Buleleng. Big potenstion to make this tradition as one of the tourist attraction, which can be held everyday. Tambakan Village has a strategic location. It close to Penelokan, one route to sangeh, plaga, Tukad Bangkung, bagus Agro to penelokan. The asumtion that the development of this tradition can increase the social income for the peoples in Tambakan Village in the future.
\end{abstract}

Keywords: tradition, tourism, development

\section{Pendahuluan}

Tradisi dan adat budaya Bali adalah sosok yang unik dengan ciri khas yang berbeda dengan kebudayaan daerah lainnya di Indonesia. Kebudayaan Bali merupakan budaya yang memiliki akar yang kokoh dan kuat, kebudayaan tersebut mampu hidup dan berkembang, bahkan budaya Bali mempengaruhi kehidupan masyarakat yang erat hubungannya dengan agama dan prilaku sosial religius masyarakat Bali yang di jiwai oleh ajaran agama Hindu. Hal ini disebabkan napas dari kebudayaan Bali adalah ajaran Agama Hindu. Yang inti ajarannya "Sanatana Dharma", yaitu satyam (kebenaran), siwam (kesucian), dan sundaram (keindahan). Ajaran ini dapat diartikan bahwa dengan menegakan kebenaran, kemuliaan dan kesucian yang berlandaskan dari keharmonisan keindahan dalam kehidupan masyarakatnya dan diaplikasikan kedalam keseimbangan yang diwujudkan dengan menunjukkan rasa bakti terhadap Tuhan/Ida Sang Hyang Widhi Wasa, lingkungan hidup dan mayarakat Bali. Hal seperti ini haruslah dilaksanakan dalam kehidupan sehari-hari sehingga kebudayaan Bali kedepannya akan tetap lestari dan dengan hal tersebut pulau Bali pada hari-hari yang akan datang tetap ajeg dan masyarakat Bali ke depan akan lebih tahan serta mempilter budaya-budaya yang masuk dan mengaplikasikan kedalam kehidupan agar dapat 
menyatu dengan kehidupan sosial religius tanpa mengurangi kebudayaan, adat dan tradisi yang sudah ada, sehingga dapat menetralaisir budaya luar yang belum tentu sesuai dengan budaya adat dan tradisi Bali itu sendiri.

Salah satu kebudayaan yang unik dan masih eksis sampai sekarang di Bali yaitu tradisi Magoak-goakan. Salah satu dari sekian desa yang masih melestarikannya yaitu Desa Pakraman Tambakan, Kec Kubutambahan, Kabupaten Buleleng. Keunikan Magoak-goakan dapat di lihat dari proses sebelum tradisi ini dilaksanakan. Tradisi adat ini tidak sembarangan dilaksanakan, merupakan tradisi yang sakral di wariskan secara turun-temurun dari generasi ke generasi berikutnya. Tradisi ini sudah menjadi bagian dari kehidupan masyarakat Desa Pakraman Tambakan.

Magoak-goakan di Desa Pakraman Tambakan dilaksanakan berkaitan dengan upacara Penyepian Desa. Sebelum tradisi Magoak-goakan, maka terlebih dahulu dilaksanakan upacara mesegeh dengan sarana hewan sapi. Upacara ini juga disebut dengan Upacara Mungkah Wali (pembuka upacara-upacara atau ritual berikutnya di Desa Tambakan) tepatnya pada Purnama Sasih Kasa yang dilaksanakan setiap dua tahun sekali.

Tradisi Magoak-goakan nampaknya dapat dikembangkan menjadi salah sata daya tarik pertunjukan wisata di Desa Tambakan yang belum digarap sampai saat ini. Padahal tradisi ini sangat unik dan tidak semua desa di Bali melaksanakannya. Berdasarkan latar belakang masalah tersebut diatas maka dapat penting untuk diangkat beberapa permasalahan antara lain: 1). Bagaimana Keberadaan Tradisi Magoak-goakan pada Penyepian Desa di Desa Pakraman Tambakan? 2) Bagaimana potensi wisata dan ekonomi Tradisi Magoak-goakan Pada Penyepian Desa Di Desa Pakraman Tambakan, Kecamatan Kubutambahan, Kabupaten Buleleng?

Secara umum tujuan penelitian ini adalah untuk memberikan pengatahuan di kalangan masyarakat pada umumnya dan pada bahwa pada masyarakat Desa Tambakan Kecamatan Kubutambahan Kabupaten Buleleng terhadap tradisi Magoak-goakan yang dapat dikembangkan menjadi daya trarik pertunjukan wisata. Tujuan khususnya adalah untuk mengetahui bagaimana bentuk tradisi megoak-goakan dan potensinya sebagai daya tarik pertunjukan wisata.

\section{Pembahasan}

Tradisi Magoak-goak berasal dari ki barak panji sakti yang mempunyai pengikut dan diberi nama truna goak untuk menyerang Kerajaan Blambangan yang di mana ki barak panji sakti ingin memperluas kekuasaanya dengan mengusai kerajaan Blambangan. Magoak-goakan dalam Kamus Bahasa BaliIndonesia memiliki arti permainan anak-anak yang berleret ke belakang, anak yang didepan berhadapan sendiri menjadi gagak mengejar ekor (anak) yang paling belakang (Warna, 1991: 237).

Tradisi magoak-goakan yang dilaksanakan masyarakat Desa Pakraman Tambakan sangat unik, di mana tradisi magoak-goakan ini melibatkan orang dewasa, remaja, dan anak-anak. Dalam permainan magoak-goakan, masyarakat berkumpul di lapangan yang ada di lapangan desa, dimana lapangan ini di percaya memiliki kesucian. Cara permainan magoak-goakan adalah dengan membuat barisan dua kelompok, barisan laki-laki dan perempuan, saling memegang selendang yang 
didepannya, yang kemudian yang paling depan bertugas untuk mengejar lawan yang paling belakang. Tradisi berasal dari kata "traditium" pada dasarnya berarti segala sesuatu yang di warisi dari masa lalu. Tradisi merupakan hasil cipta dan karya manusia objek material, kepercayaan, khayalan, kejadian, atau lembaga yang di wariskan dari sesuatu generasi ke generasi berikutnya. Seperti misalnya adat-istiadat, kesenian dan properti yang digunakan

Menurut Arwati (2008: 3) menyatakan, secara umum Nyepi merupakan salah satu hari raya Hindu sebagai upacara perayaaan Tahun Baru Saka yang dirayakan oleh umat Hindu di Indonesia secara khusus melalui pelaksanaan catur brata, yaitu: Amati Agni, Amati Karya, Amati Lalanguan, Amati Lelungaan. Perayaan Nyepi dilaksanakan pada tanggal satu waisakha, yaitu sehari stelah hari Tilem Sasih Ka Sanga/pada hari pertama Sasih Ka Dasa.

Nyepi berasal dari kata sepi (sunyi, senyap). Kata "sepi" dalam kamus Bahasa Indoensia berarti tidak ramai, mangasingkan diri dari keramaian (Badudu, 2008: 319). Pelaksanaan Nyepi di Bali adalah memohon ke hadapan Tuhan Yang Maha Esa/Ida Sang Hyang Widhi Wasa, untuk menyucikan Bhuana Alit (alam manusia/microcosmos) dan Bhuana Agung/macrocosmos (alam semesta) untuk mewujudkan kesejahtraan dan kebahagiaan lahir batin (jagadhita dan moksa), terbinanya kehidupan yang berlandaskan satyam (kebenaran) siwam (kesucia) dan sundaram (keharmonisan/keindahan) (Arwati, 2008: 9).

Penyepian Desa yang diselenggarakan oleh masyarakat Desa Pakraman Tambakan bertujuan untuk menyucikan alam berserta dan segala isinya dengan beberapa brata/larangan yang harus ditaati. Penyepian Desa/Nyepi Adat hanya mencangkup masyarakat di Desa Pakraman Tambakan dan berlangsung satu hari (wawancara, Jro Bendesa 15 Agustus 2018).

Tradisi Magoak-goakan ini masih dilaksanakan serangkaian hari Raya Nyepi Desa yang dilaksanakan hingga sekarang. Magoak-goakan sudah menjadi bagian kehidupan masyarakat di Desa Pakraman Tambakan yang dijalankan setiap satu tahun sekali yang merupakan bagian dari pelaksanaan upacara Penyepian Desa/Nyepi Adat. Pelaksanaan tradisi Magoak-goakan di awali dengan rangkian upacara Penyepian Desa, yang di laksanakan setiap satu tahun sekali dengan rangkian pelaksanan upacaranya di mulai dengan melaksanakan upacara:

Ada suatu aturan yang harus ditaati dalam melaksanakan tradisi Magoak-goakan tersebut, yaitu: 1) peserta tidak boleh emosi, 2) peserta tidak boleh curang, 3) peserta tidak boleh curiga, 4) peserta tidak boleh mengeluarkan kata-kata yang tidak sopan misalnya memisuh. Bila ada peserta yang melanggar aturan tersebut maka akan terjadi sesuatu yang akan membahayakan, misalnya akan keseleo, patah, atau luka. Bila hal tersebut terjadi biasanya yang bersangkutan naur "kesisipan" ke Desa dengan mengaturkan canang dan jinah pis bolong ke Pura Dalem Pinggit di pimpin oleh salah satu dulun desa. Kemudian di berikan tirtha, tak sampai lama maka keseleonya atau lukanya akan sembuh.

Banyak keanehan dalam permainan Magoak-goakan tersebut, keanehannya adalah terletak pada permainannya, di mana dalam permainan Magoak-goakan tersebut sangat keras, benturan denga teman ataupun pada benda-benda keras di lapangan tidak terhindarkan, akan tetapi bila dilakukan dengan penuh keyakinan dan didasari atas niat ngaturah ngayah kepada Ida Ratu Sesuhunan Dalem maka tidak 
akan celaka, seperti: keseleo, luka, patah dan sejenisnya. Atas dasar kejadiankejadian seperti itulah menyebabkan kepercayaan Krama Desa Pakraman Tambakan semakin dalam tentang Magoak-goakan tersebut.

Permainan Magoak-goakan inipun merupakan suatu lambang purusa dan pradana. Selain hal tersebut, permainan ini merupakan perwujudan Unen-unen BetaraBetari Dalem (bhuta kala) yang pada saat Penyepian Desa bergembira, bersenang-senang setelah mendapatkan labaan pada saat mesegeh, mecaru dan tawur di kalang beten, kegembiraan tersebut di wujudkan oleh umat/krama Desa Pakraman Tambakan dalam permainan tersebut.

Tradisi Magoak-goakan ini masih dilaksanakan hingga sekarang ini. Walapun jaman sudah maju dan banyak pengaruh-pengaruh budaya asing, akan tetapi tradisi ini masih eksistensi dikalangan masyarakat Desa Pakraman Tambakan dan menjadi bagian kehidupan sosial religius masyarakat Desa Pakraman Tambakan.

Banyak warisan budaya dan tradisi unik yang masih bertahan hingga sekarang. Salah satunya adalah tradisi megoak goakan di Desa Tambakan Kabupaten Buleleng. Kawasan Bali utara atau Kabupaten buleleng memiliki banyak objek wisata antara lain Pantai Lovina, air terjun gitgit, air saneh, pura Beji sangsit dan lain lain. Salah satu yang menarik adalah tradisi megoak goakan yang berasal dari Desa Panji. Megoak goakan di inspirasi oleh seekor burung goak (gagak) yang sedang mengincar mangsanya. Tradisi ini masih bertahan hingga sekarang di tengah bentuk permainan tradisional anak anak yang semakin hilang. Hal ini tidak terlepas karena tradisi ini masih ada kaitannya dengan pelaksanaan upacara keagamaan di Desa Tambakan yaitu pada upacara atau ritual Nyepi Desa.

Tradisi ini juga tetap berlangsung dalam rangka menghormati jasa dari Raja Ki Barak Panji Sakti pada saat masa pemerintahan kerajaan Buleleng. Dan beliau sendiri yang menemukannya dalam rangka pembelajaran taktik perang atau menagkap mangsa dalam permainan yang seru. Dan raja meminta jika sang Raja menang maka ia meminta prajuritnya atau rakyatnya memenuhi keinginannya berperang untuk merebut wilayah Blambangan. Permainan dilakukan dalam dua kelompok atau regu. Dalam permainan ini pemimpin regu harus dapat menangkap peserta regu yang paling belakang. Siapa yang berhasil duluan dialah pemenangnya.

Tradisi ini sangat berpotensi menjadi daya tarik wisata untuk dikembangkan lebih lanjut. Desa Tambakan yang letaknya dekat dengan Objek wisata Penelokan Tambakan sangat memungkinkan untuk mengembangkannya. Sebagian besar masyarakat adalah petani dan peternak sehingga lebih mudah untuk mengelolanya. Masyarakat tidak terikat waktu untuk melaksanakannya. Di samping itu Desa Tambakan juga dekat dengan jalur wisata sangeh, petang waterpark, Jembatan Tukad bangkung dan Bagus Agro di Plaga. Pementasan ini juga bisa dikombinasikan dengan melihat kehidupan sehari-hari masyarakat Desa Tambakan.

Semua kegiatan/aktifitas yang dilakukan oleh masyarakat sudah pasti akan menimbulkan suatu dampak. Begitu juga dengan aktivitas yang dilaksanakan oleh masyarakat Desa Pakraman yang melaksanakan tradisi Magoak-goakan pada Penyepian Desa. Berbagai dampak terjadi dari aktivitas yang dilaksanakan ini, salah satunya adalah dampak sosial ekomoni. Globalisasi merupakan penduniaan 
nilai-nilai budaya, adat, tradisi ke kehidupan masyarakat yang ada di daerah lain dan dari negara ke negara lain. Proses penduniaan adalah proses perubahan sosial yang cepat, di mana telah ketahui pada era modern dan globalisasi di ikuti dengan perkembangan teknologi yang mempermudah masyarakat untuk melintasi ruang dan waktu budaya umat manusia yang ada di setiap negara-negara lain di dunia ini.

Budaya Bali yang kental dengan tradisi serta adat istiadat di dalam kehidupan sosialnya, jika tidak dipertahankan keberadaanya, sudah tentu akan terancam eksistensinya. Apalagi era gobalisasi seperti sekarang ini. Keberadaan tradisi Magoak-goakan di Desa Pakraman Tambakan memberikan dampak positif bagi para genersasi muda Desa Pakraman Tambakan yang masih mau ikut menjalankan tradisi ini sekaligus untuk tetap mempertahankan budaya Bali.

Dampak Sosial dari pelaksanaan tradisi Magoak-goakan pada Penyepian Desa di Desa Pakraman Tambakan adalah meningkatkan rasa kekerabatan yang kuat antar Banjar di Desa Pakraman Tambakan, di mana masyarakat menjadi satu kesatuan hidup yang bersifat tradisional, adanya ikatan adat dan kebiasaan, norma, pola tingkah laku, pandangan hidup yang diterima secara turun menurun dari generasi kegenerasi. Dari adanya suatu rasa keterikatan maka timbul rasa saling membutuhkan dan rasa solidaritas antar sesama masyarakat Desa Pakraman Tambakan yang sangat kuat. Hal ini di sebabkan, karena dengan pelaksanaan tradisi Magoak-goakan ini memberikan kesempatan untuk berkumpul bagi seluruh masyarakat Desa Pakraman Tambakan. Hubungan yang terjadi dalam masyarakat tersebut, maka dengan pelaksanaan tradisi Magoak-goakan ini menimbulkan dampak sosial yang sangat dirasakan oleh masyarakat Desa Pakraman Tambakan.

Dampak secara Ekonomi pada setiap pementasan tradisi megoak goakan para pedagang warung akan membuka lapak di sekitar lapangan. Mereka berjualan jajan dan jenis minuman atau bahkan berjualan nasi. Potensi ekonomi ini tidak saja akan berdampak pada pedagang apabila tradisi ini dikembangkan menjadi daya tarik pertunjukan wisata. Desa dapat mengelolanya dengan memungut karcis dan parkir bagi wisatawan. Dan bahkan bisa dipertunjukkan meskipun bukan pada saat Nyepi Desa saja. Pertunjukan ini dapat dimodifikasi menjadi pertunjukan yang rutin dilaksanakan seperti pertunjukan tari Barong di Batubulan.

Dengan potensi yang ada dan promosi yang gencar, keyakinan tradisi ini dapat dikembangkan menjadi daya tarik wisata yang diminati dan dapat menumbuhkan perekonomian dan kesejahteraan masyarakat Desa Tambakan.

\section{Daftar Pustaka}

Arwati, Ni Made Sri. 2008. Hari Raya Nyepi.

Reuter, Thomas A. 2005. Custodians of the sacred mountains Budayadan Masyarakat di pegunungan Bali. Jakarta: YayasanObor Indonesia. 
Resmiani, Desak Putu Sri.2010.Tradisi Megoak-goakan Sebagai Kearifan Lokal Pada Hari Ngembak Nyepi Di Desa Panji Kecamatan Sukasada Kabupaten Buleleng (kajian Nilai-nilai Pendidikan Agama Hindu).

Warna, I Wayan.1991.Kamus Bali-Indonesia. Dinas Pendidikan Dasar Propinsi Dati I Bali.

Yoeti, Oka A. 1996. Pengantar Ilmu Pariwisata. Angkasa: Bandung. 